\title{
Detection of extended spectrum beta- lactamases and antibiogram profile of Klebsiella species
}

\author{
Asmaa Z. Al-Gerir \\ Department of Microbiology, College of Medicine, University of Mosul.
}

(Ann. Coll. Med. Mosul 2012; 38 (1): 33-39).

Received: $13^{\text {th }}$ Mar. 2011; Accepted: $1^{\text {st }}$ Nov. 2011.

\begin{abstract}
Objectives: 1). To determine the prevalence of ESBLs producing Klebsiella species. 2). To examine their antibiogram profile. 3). To evaluate the association between ESBLs production and antibiotics resistance in Klebsiella isolates.

Materials and methods: This prospective study included 116 non repeated isolates of Klebsiella species 62 obtained from urine and 54 recovered from wounds. These bacterial isolates were reidentified and tested for antibiotic sensitivity against 19 selected antimicrobial agents. Also, these isolates were evaluated for extended spectrum beta lactamases (ESBLs) by double disk synergy test. Results: Extended spectrum beta lactamases were found to be produced by $16.4 \%$ of the total studied Klebsiella isolates. Amikacin showed the lowest resistance rate (27.6\%), while the highest one was detected against cephalothin, penicillin, cloxacillin and ampicillin (98.3\%). The statistical analysis between ESBLs production and antibiotics resistance revealed a significant association only with ceftriaxone $(p<0.05)$, cefotaxime $(p<0.001)$, cefixime $(p<0.001)$, gentamicin $(p<0.05)$ and nitrofurantoin $(p<0.05)$. Moreover, it was found that the strains produced ESBLs showed a higher resistance to all the used antibiotics except for levofloxacin.

Conclusions: This study highlights the emergence of ESBLs producing strains of Klebsiella, which endowed with extremely wide spectrum of antibiotics resistance including resistance to pencillins, cephalosporin, aminoglycosides and fluroqunilones. This increased resistance to antimicrobial agents may result in treatment failure.
\end{abstract}

الخلاصة

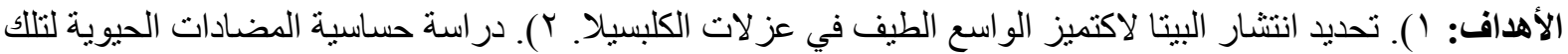

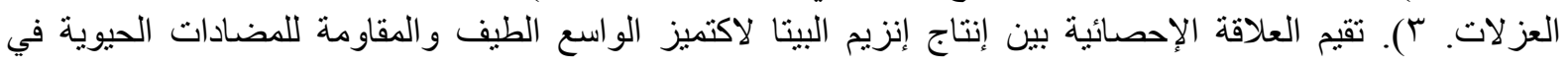
جرثومة الكلبسيلا. المواد والطرق: هذه الدر اسة تضمنت 11717 عزلة غير متكررة من جرثومة الكلبسيلا, بالو منها جمعت من عينات البول و

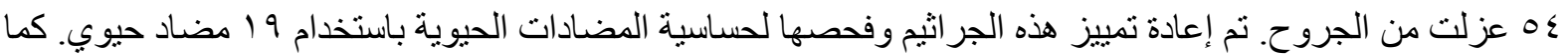

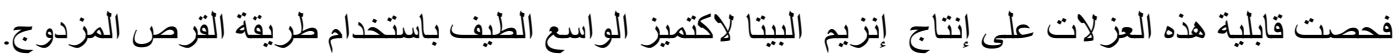

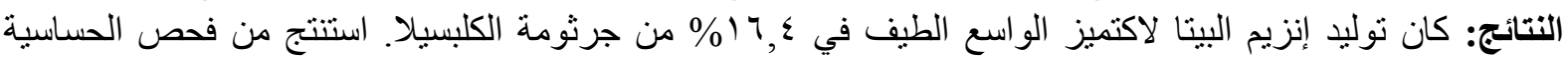

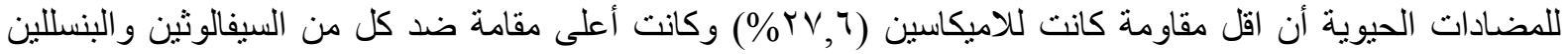

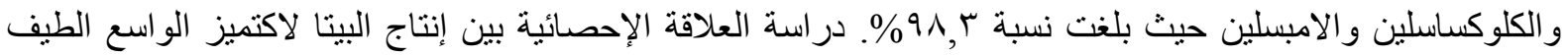

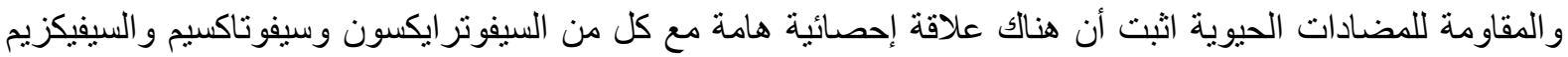

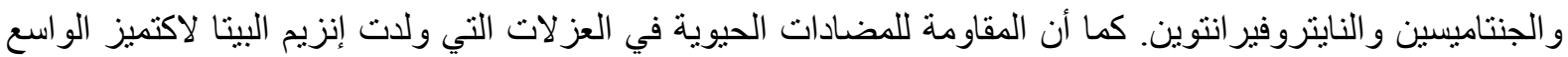
الطيف أعلى من الجر اثيم التي لم تنتجه. 


$$
\begin{aligned}
& \text { الاستتتاجات: ثبرز هذه الدراسة ظهور عزلات للكلبسيلا المولدة لانزيم البيتا لاكتميز الواسع الطيف، مما أدى إلى زيادة }
\end{aligned}
$$

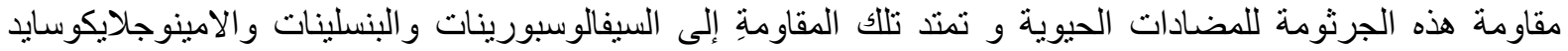

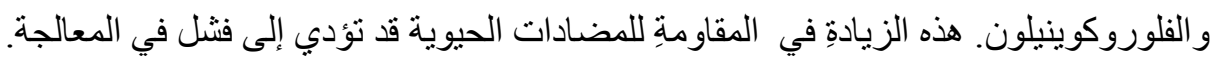

K lebsiella is an opportunistic pathogen and has been associated with various infections such as urinary tract infection (UTI), septicemia, wound infection, respiratory tract infection and diarrhea ${ }^{(1)}$. The resistant strains of Klebsiella gain their resistance by producing the enzymes extended spectrum beta lactamases (ESBLs), which are predominantly Bush class $A^{(2)}$.

The ESBLs are defined as enzymes capable of hydrolyzing and inactivating a wide variety of beta lactam drugs including third generation cephalosporins, penicillins and aztreonam. The majority of ESBLs are results of mutation of TEM1, TEM2 and SHV genes ${ }^{(3)}$. They are now distinguished into more than 30 types based on their physical properties, and all are inhibited by clavulante, sulbactam and tazobactam, a property which has been used to detect them ${ }^{(1)}$. All these beta lactamases are found in a variety of species of the family Enterobacteriaceae. The majority of ESBLS producing strains are Klebsiella pneumoniae, Klebsiella oxytoca and Escherichia coli. Other organisms reported to harbor ESBLs include Enterobacter species, Salmonella species, Morganella morganii, Proteus mirabilis, Serratia marcescens and Pseudomonas aeruginosa. However, the frequency of ESBLs production in these bacteria is low ${ }^{(4)}$. The ESBLs producing strains are probably more prevalent than currently recognized because they are often not detected by routine susceptibility testing methods ${ }^{(1)}$.

The ESBLs are encoded by transferable conjugative plasmids, which are often coexisting on the same plasmid encoding the mechanism of resistance to different antibiotics ${ }^{(5)}$. Recent reports have recorded the emergence of ESBLs producing Klebsiella strains with an extremely wide spectrum of antibiotics resistance, such as resistance to aminoglycosides, fluoroquinolones, tetracycline, chloramphenicol and sulfonamide ${ }^{(4,6)}$.
The beta lactamases mediated resistance may be overcome by combining beta lactam antibiotics with beta lactamases inhibitor which bind irreversibly to beta lactamases rendering them inactive thus sparing the beta lactam antibiotics $^{(7)}$.

The National Committee for Clinical Laboratory Standards (NCCLS) recommended ESBLs screening method and confirmatory test ${ }^{(8)}$. However, their use in microbiology laboratories has been neglected. Delay in the detection and reporting of ESBLs production by gram negative bacteria is associated with prolonged hospital stay and increased morbidity, mortality and health care costs ${ }^{(9)}$. Institutional microbial sensitivity tests or local patterns of susceptibility are the first steps that are crucial for treatment of ESBLs producing bacteria.

\section{Aims of the study}

The present study was conducted with objectives to determine the prevalence of ESBLs producing Klebsiella species and to examine their antibiogram profile. In addition, to evaluate the association between ESBLs production and antibiotics resistance.

\section{Materials and methods Bacterial isolates}

A total of 116 non-repeated isolates of Klebsiella were collected from 4 different Teaching Hospitals in Mosul- Iraq during a period from September 2010 to January 2011. The specimens yielded these bacterial strains included urine (62) and wound swabs (54). The bacterial isolates were re-identified using the conventional bacteriological and biochemical tests ${ }^{(10)}$.

\section{Antimicrobial sensitivity testing}

Antimicrobial sensitivity test was done using disk diffusion method against 19 selected antimicrobial agents according to NCCLS guide lines ${ }^{(11)}$. A bacterial suspension with 
turbidity equal to 0.5 McFerland was prepared and this suspension was inoculated on Mueller- Hinton agar plate using a sterile swab. The following antibiotics were tested amikacin (10 mcg), levofloxacin (5 mcg), ciprofloxacin $(5 \mathrm{mcg})$, norfloxacin $(10 \mathrm{mcg})$, enrofloxacin $(10 \mathrm{mcg})$, nalidixic acid $(30 \mathrm{mcg})$, nitrofurantoin $(100 \mathrm{mcg})$, kanamycin $(30 \mathrm{mcg})$, gentamicin $(10 \mathrm{mcg})$, cefotaxime $(10 \mathrm{mcg})$, cefixime $(5 \mathrm{mcg})$, ceftriaxone $(10 \mathrm{mcg})$, cefoxitin (30 $\mathrm{mcg})$, piperacillin $(30 \mathrm{mcg})$, cephradine $(30 \mathrm{mcg})$, penicillin $(10 \mathrm{mcg})$, cephalothin $(30 \mathrm{mcg})$, cloxacillin $(10 \mathrm{mcg})$, ampicillin $(30 \mathrm{mcg})$.

\section{Screening for Beta lactamases production}

The Klebsiella isolates were tested for their ability to produce beta lactamases using direct rapid iodometeric method. These isolates were further tested for their ability to produce ESBLS using double disk synergy test. This test was done to determine the synergy between a disk of amoxicillin/ clavulanic acid $(20 \mathrm{mcg} / 10$ $\mathrm{mcg}$ ) and cefotaxime disk (30 $\mathrm{mcg})$. These two disks were placed on inoculated Mueller Hinton agar at a distance of $2.5 \mathrm{~mm}$ center to center. A positive result was defined as a 5 $\mathrm{mm}$ or more increase in zone of inhibition diameter compared to disk without clavulanic $\operatorname{acid}^{(12)}$

\section{Results}

In the present work, 116 isolates of Klebsiella were collected (62 from urine and 54 from wound infection), Klebsiella pneumoniae represented $65.5 \%$ of the total isolates, while Klebsiella oxytoca formed $34.5 \%$ of the studied microorganisms.

The beta lactamases were detected using the rapid iodometric method, $67.2 \%$ of the total Klebsiella strains were rapid beta lactamases producers. Furthermore, the formation of ESBLs in these strains was also evaluated, $16.4 \%$ were ESBLs producers while $83.6 \%$ of them were non producers (Figure 1).

In the current study, Klebsiella pneumoniae produced ESBLs in a higher percentage than that of Klebsiella oxytoca (11.2, 5.2 respectively). The statistical analysis of ESBLS formation and the difference in species revealed no significant association (Table 1).
Concerning the site of isolation and ESBLs production, Klebsiella strains isolated from wounds produced ESBLs in a rate of $18.5 \%$, in comparison to $14.5 \%$ recovered from urine. However, the statistical analysis showed no significant difference between these two values (Table 2).

The antibiogram profile of Klebsiella isolates was determined against a panel of antimicrobial agents. The microorganism revealed the lowest resistance rate $(27.6 \%)$ against amikacin, while the highest rate was detected against cephalothin, penicillin, cloxacillin and ampicillin (98.3\%) as presented in table 3. Klebsiella isolated from wounds showed a higher resistance rate than those recovered from urine against all the tested drugs except cefoxitin, enrofloxacin, cefotaxime and nalidixic acid (Table 3).

The statistical association between ESBLs production and resistance to antibiotics was evaluated using $X^{2}$ test, the drugs that showed a statistical association were ceftriaxone $(p<0.05)$, cefotaxime $(p<0.001)$, cefixime $(p<0.001), \quad$ gentamicin $\quad(p<0.05) \quad$ and nitrofurantoin $\quad(p<0.05)$. The remaining antibiotics revealed no significant association (Table 4). Although there was no significant statistical difference between resistance to most of the tested drugs and ESBLs formation, the strains produced ESBLs showed a higher resistance to all the used antibiotics except for levofloxacin (Table 4).

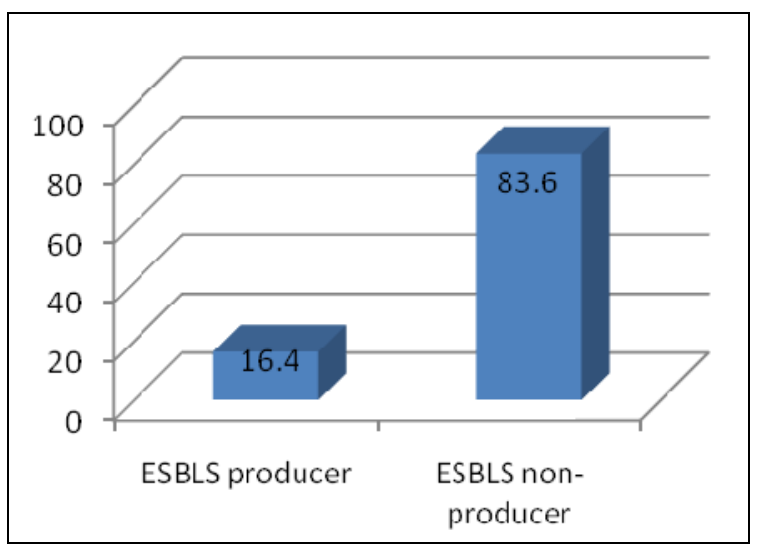

Figure (1): Rates of ESBLS producer and non producer in Klebseilla species. 
Table (1): Percentages of ESBLs production in Klebsiella pneumoniae and Klebsiella oxytoca.

\begin{tabular}{|l|c|c|c|c|}
\hline \begin{tabular}{|l|c|} 
Klebsiella \\
isolates
\end{tabular} & $\begin{array}{c}\text { ESBLs } \\
\text { producers } \\
\text { No. (\%) }\end{array}$ & $\begin{array}{c}\text { ESBLS } \\
\text { non- } \\
\text { producer } \\
\text { No. (\%) }\end{array}$ & $\begin{array}{c}\text { Total } \\
\text { No. (\%) }\end{array}$ & $\begin{array}{c}\text { P } \\
\text { value }\end{array}$ \\
\cline { 1 - 4 } $\begin{array}{l}\text { Klebsiella } \\
\text { Pneumoniae }\end{array}$ & $\begin{array}{c}13 \\
(11.2)\end{array}$ & $\begin{array}{c}63 \\
(88.8)\end{array}$ & $\begin{array}{c}67 \\
(65.5)\end{array}$ & \\
\cline { 1 - 4 } $\begin{array}{l}\text { Klebsiella } \\
\text { oxytoca }\end{array}$ & $\begin{array}{c}6 \\
(5.2)\end{array}$ & $\begin{array}{c}34 \\
(94.8)\end{array}$ & $\begin{array}{c}40 \\
(34.5)\end{array}$ & \multirow{2}{*}{$<0.5$} \\
\cline { 1 - 3 } Total & $\begin{array}{c}19 \\
(16.4)\end{array}$ & $\begin{array}{c}97 \\
(83.6)\end{array}$ & 116 & \\
\hline
\end{tabular}

Table (2): Percentages of ESBLS production in wounds and urinary Klebsiella isolates.

\begin{tabular}{|c|c|c|c|c|}
\hline $\begin{array}{c}\text { Klebseilla } \\
\text { isolates }\end{array}$ & $\begin{array}{c}\text { ESBLs } \\
\text { producers } \\
\text { No. (\%) }\end{array}$ & $\begin{array}{c}\text { ESBLs } \\
\text { non- } \\
\text { producer } \\
\text { No. (\%) }\end{array}$ & $\begin{array}{l}\text { Total } \\
\text { No. } \\
(\%)\end{array}$ & $\begin{array}{c}P \\
\text { value }\end{array}$ \\
\hline Wound & $10(18.5)$ & 44 (81.5) & 54 & \multirow{3}{*}{$<0.5$} \\
\hline Urine & $9(14.5)$ & 53 (83.5) & 62 & \\
\hline Total & 19 (16.4) & 97 (83.6) & 116 & \\
\hline
\end{tabular}

Table (3): Antimicrobial resistance of Klebsiella isolates.

\begin{tabular}{|l|c|c|c|}
\hline $\begin{array}{c}\text { Antimicrobial } \\
\text { agents }\end{array}$ & $\begin{array}{c}\text { \% of } \\
\text { resistance } \\
\text { in urine } \\
\text { isolates }\end{array}$ & $\begin{array}{c}\text { \% of } \\
\text { resistance } \\
\text { in wound } \\
\text { isolates }\end{array}$ & $\begin{array}{c}\text { \% of } \\
\text { resistance in } \\
\text { total isolates }\end{array}$ \\
\hline Amikacin & 25.8 & 29.6 & 27.6 \\
\hline Levofloxacin & 22.3 & 40.7 & 31 \\
\hline Ciprofloxacin & 32.3 & 37 & 34.4 \\
\hline Norfloxacin & 35.5 & 40.7 & 37.9 \\
\hline Enrofloxacin & 45.2 & 37 & 41.3 \\
\hline Nalidixic acid & 41.9 & 40.7 & 41.4 \\
\hline Nitrofurantoin & 41.9 & 48.1 & 44.8 \\
\hline Kanamycin & 48.1 & 51.9 & 50 \\
\hline Gentamicin & 64.5 & 74.1 & 69 \\
\hline Cefotaxime & 74.2 & 70.4 & 72.4 \\
\hline Cefixime & 59 & 81.5 & 74.1 \\
\hline Ceftriaxone & 80.6 & 81.5 & 81 \\
\hline Cefoxitin & 90.3 & 81.5 & 86.2 \\
\hline Piperacillin & 87.1 & 89.9 & 87.9 \\
\hline Cephradine & 93.5 & 100 & 96.8 \\
\hline Penicillin & 96.7 & 100 & 98.3 \\
\hline Cephalothin & 96.7 & 100 & 98.3 \\
\hline Cloxacillin & 96.7 & 100 & 98.3 \\
\hline Ampicillin & 96.7 & 100 & 98.3 \\
\hline
\end{tabular}

Table (4): Percentages of antimicrobial resistance and $P$-value results in ESBLS producer and non producers Klebsiella strains.

\begin{tabular}{|l|c|c|c|c|}
\hline $\begin{array}{c}\text { Antimicrobial } \\
\text { agent }\end{array}$ & $\begin{array}{c}\text { \% of } \\
\text { resistance } \\
\text { in ESBLs } \\
\text { producer } \\
\text { isolates }\end{array}$ & $\begin{array}{c}\text { \% of } \\
\text { resistance } \\
\text { in ESBLs } \\
\text { non } \\
\text { producer } \\
\text { isolates }\end{array}$ & $\begin{array}{c}\text { X }^{2} \text { test } \\
\text { results }\end{array}$ & $\begin{array}{c}\text { P- } \\
\text { value }\end{array}$ \\
\hline Amikacin & 42.1 & 24.7 & 0.1607 & $<0.5$ \\
\hline Levofloxacin & 21.1 & 32.9 & 0.5735 & $<0.5$ \\
\hline Ciprofloxacin & 36.8 & 34 & 0.0225 & $<0.5$ \\
\hline Norfloxacin & 42.1 & 37.1 & 0.022 & $<0.5$ \\
\hline Enrofloxacin & 52.6 & 39.2 & 0.696 & $<0.5$ \\
\hline Nalidixic acid & 63.7 & 37.1 & 3.434 & $<0.1$ \\
\hline Nitrofurantoin & 68.4 & 40.2 & 4.0367 & $<0.05$ \\
\hline Kanamycin & 57.9 & 48.5 & 0.251 & $<0.5$ \\
\hline Gentamicin & 84.2 & 60.8 & 4.0169 & $<0.05$ \\
\hline Cefotaxime & 100 & 77.7 & 7.0381 & $<0.001$ \\
\hline Cefixime & 100 & 69.1 & 6,3951 & $<0.001$ \\
\hline Ceftriaxone & 100 & 77.3 & 3.8789 & $<0.05$ \\
\hline Cefoxitin & 100 & 91.8 & 0.643 & $<0.5$ \\
\hline Piperacillin & 100 & 85.6 & 1.906 & $<0.5$ \\
\hline Cephradine & 100 & 95.9 & 0.045 & $<0.5$ \\
\hline Penicillin & 100 & 98.9 & 0.8411 & $<0.5$ \\
\hline Cephalixin & 100 & 98.9 & 0.8411 & $<0.5$ \\
\hline Cloxacillin & 100 & 98.9 & 0.8411 & $<0.5$ \\
\hline Ampicillin & 100 & 98.9 & 0.8411 & $<0.5$ \\
\hline & & & & \\
\hline
\end{tabular}

\section{Discussion}

Klebsiella is an important nosocomial pathogen that has the potential to cause severe morbidity and mortality. In the present work, Klebsiella pneumoniae was isolated from the clinical samples in a higher percentage than Klebsiella oxytoca, which was consistent with other workers ${ }^{(13)}$.

The prevalence of ESBLs producing bacteria in most hospitals remains unknown in spite of numerous reports of nosocomial outbreaks of infections due to these microorganisms. In this study, the percentage of Klebsiella produced ESBLs was $16.4 \%$, which was in agreement with the result recorded by other researchers $(14,15)$. On the other hand, Shubla and Ananthan reported a lower incidence $(6 \%)^{(1)}$, while other worker mentioned a higher (40\%) one ${ }^{(16,17)}$. The occurrence of ESBLs varied from one locality to another, which may be due to infection control practice among different regions or to the difference in the uses of new extended spectrum antimicrobial agents. 
Klebsiella pneumoniae isolates produced ESBLs in a higher percentage than Klebsiella oxytoca. Mulvey and coworkers (2004) reported the same results ${ }^{(13)}$. Furthermore, there was no significant statistical association between the species and ESBLs formation which was in agreement with the findings of Hosoglu and his coworkers ${ }^{(18)}$. This result may be explained on the basis that ESBLs production is plasmid mediated which is transferred to different bacteria regardless of their species. Moreover, the strains isolated from wound infection produced ESBLs in percentage higher than those recovered from urinary isolates, which simulate the work of others ${ }^{(19)}$.

The antibiogram study of Klebsiella isolates showed a higher resistance against penicillines and the first and second generation cephalosporines (98.3\%); similar results were reported by other researchers ${ }^{(17}$, 20). The resistance against third generation cephalosporines especially ceftriaxone was high (81\%), while cefotaxime and cefixime were more effective agents. Other investigators reported similar results ${ }^{(17)}$, while a lower resistance (54\%) was recorded by other investigators. ${ }^{(20)}$

Aminoglycosides have a good effect against the clinically important gram negative bacilli ${ }^{(21)}$. In the current study, amikacin showed the lowest resistance rate (27.96\%). This result was similar to the findings $(26.96 \%)$ of Ullah and his colleagues ${ }^{(20)}$, although it was higher than the result observed by Aminzahed and his coworkers ${ }^{(17)}$ and lower than that of Revathi and Puri ${ }^{(22)}$. Since the least resistance was against amikacin, it may serve as the drug of choice in treating infection caused by Klebsiella strains, where the organism showed a resistance rate of $69 \%$ and $50 \%$ to gentamicin and kanamycin respectively. These results were in concinnity with the work of Ullah and his colleagues ${ }^{(20)}$, while Revathi and Puri ${ }^{(22)}$ reported a less effectiveness of these two drugs.

The observed resistance to ciprofloxacin, norfloxacin, nalidixic acid and nitrofurantoin were $34.4 \%, \quad 37.9 \%, \quad 41.4 \%$ and $44.8 \%$ respectively. These findings were in agreement with the results recorded by another work ${ }^{(17)}$. Ullah and his coworkers ${ }^{(20)}$ recorded a higher resistance rate against ciprofloxacin (52.17\%) while Procop and colleagues ${ }^{(23)}$ reported a lower resistance rate (20\%). Moreover, the resistance percentage against levofloxacin was $31 \%$, so this drug might be still a good choice for treatment of infections caused by Klebsiella.

A significant statistical difference in susceptibility profile between ESBLs producers and ESBLs non producers Klebsiella species to ceftriaxone, cefotaxime and cefixime, was recorded during the study. These findings were consistent with the results of other workers ${ }^{(24)}$. Also, there was a significant difference between gentamicin and nitrofurantoin which goes with the work of Procop and colleagues ${ }^{(23)}$. The resistance to ciprofloxacin, amikacin and nalidixic acid had no significant differences with the production of ESBLs which were inconsistence with another study ${ }^{(23)}$.

Furthermore, the Klebsiella strains produced ESBLs were more resistant to almost all the tested antimicrobial agents than the non producer ones, similar observation has been reported by Mulvey and his coworkers ${ }^{(13)}$. This high antibacterial resistance in ESBLS producing microorganisms has caused major therapeutic problems all over the world. These findings support the hypothesis that ESBLS producing strains were more likely to have diminished susceptibility to non-beta lactam antibiotics as well as beta lactam ones compared with ESBLs non-producing isolates. Therefore, the accurate detection and reporting of ESBLs production in clinical isolates is of great importance.

\section{Conclusion}

This study highlights the emergence of ESBLs producing strains of Klebsiella, which endowed with extremely wide spectrum of antibiotics resistance including resistance to penicillins, cephalosporins, aminoglycosides and fluroquinolones. This increased resistance to antimicrobial agents may cause failure in treatment of infection caused by these microorganisms. Due to the importance of ESBLs producing organisms and difficulty in 
treatment of infection caused by these bacteria, there is a necessity for rapid identification of ESBLs. Therefore, clinical laboratories should adopt simple test based on CLSI recommendations for confirming ESBLS production in enterobacterial species and doing antimicrobial susceptibility test for precise treatment thus, avoiding haphazard therapy.

\section{References}

1. Shubha A, Ananthan S. Extended spectrum beta lactamases (ESBL) mediated resistance to third generation cephalosporines among Klebsiella pneumoniae in Chennai. Indian journal of medical microbiology 2002; 20(2):92-95.

2. Jennifer $A$, Kenneth $S$, Jonh $D$, Johan $D$. Evaluation of $B$ lactamases inhibitors in Disk Tests for detection of plasmid mediated Amp C B - lactmase $s$ in well characterized clinical strains of Klebsiella spp. Journal of clinical microbiology 2005; 43(8): 4168-4171.

3. Chaudhary $U$, Aggarwal R. Extended spectrum lactamases (ESBL) an emerging threat to clinical therapeutics. Indian journal of medical microbiology 2004; 22(2): 75-80.

4. Nathisuwan S, Burgess D, Lewis J. ESBL: Epidemiology, Detection and treatment. Pharmacotherapy 2001, 21(8): 920-928.

5. Naschi L, Shahchergahi F, Sadat V, et al. PER, CTX-M, TEM and SHV beta lactamases in clinical isolates of Klebsiella pneumoniae isolated from Tehran, Iran. Iranian journal of basic medical science 2010; 13(3): 111-118.

6. Abigail $S$, Mathai $E$, Jesudasan MV, John TJ. Ceftazidime resistance among Klebsiella pneumoniae in south India. Indian J. Med. Res. 1995; 102:53-55.

7. Monhanty S, Singhal R, Sood S. Comparative in vitro activity of beta lactam I beta lactamases inhibitor combinations against gram negative bacteria. Indian J. Med. Res. 2005; 122:425-428.

8. National Committee for Clinical Laboratory Standards. Approved standards M-100S10. Performance standards for antimicrobial susceptibility testing Wayne
(USA): National Committee for Clinical Laboratory Standards 2000.

9. Kollef $\mathrm{MH}$. The importance of appropriate initial antibiotic therapy for hospital acquired infection. Amj. Med. 2003; 115: 582-584.

10. Collee JG, Fraser AG, Marimion BP, et al. Laboratory control of antimicrobial therapy, Mackie and Mac Cartney Practical Medical Microbiology. $14^{\text {th }}$ ed. 1996.

11. National Committee for Clinical Laboratory standards 2004. Performance standards for antimicrobial susceptibility testing, $14^{\text {th }}$ informational supplement M100-S14. National Committee for Clinical laboratory standards Wayne, $\mathrm{Pa}$.

12. National Committee for clinical Laboratory Standards 2005. Performance standards for antimicrobial susceptibility testing $.15^{\text {th }}$ informational supplement (M100-s15) NCCLS.

13. Mulvey M, Bryce E, Boyd D, et al. Ambler class A. extended spectrum beta lactamases producing Escherichia coli and Klebsiella spp in Canadian Hospitals. Antimicrobial agents and chemotherapy 2004; 48(4): 1204-1214.

14. Fridkin SK, Steward CD, Edwards JR, et al. Surveillance of antimicrobial use and antimicrobial resistance in United States hospitals; project ICARE phase 2. Clin. Infect. Dis. 1999; 29(2): 245-252.

15. Chlebicks MP. Extended spectrum beta lactamases in clinical isolates of $E$. coli and Klebsiella spp. In Singapore Hospitals. Ann- Acad. Med. Singapore. 2004; 33: 302-306.

16. Ali AM, Rafi S, Qureshi AH. Frequency of extended spectrum beta lactamases producing gram negative bacilli among clinical isolates at clinical laboratories of Army Medical College, Rawalpindi. Ayub Med Coll Abottabad 2004; 16: 135-137.

17. Aminzadeh Z, Sadat Kashi M, Shabani M. Bacteriuria by extended producing Escherichia coli and Klebsiella pneumoniae: isolates in governmental hospitals in south of Tehran- Iran. Iran J. kidney Dis 2008; 2: 197-200. 
18. Hosoglu S, Gundes S, Kolayli F, et al. Extended spectrum beta lactamases in ceftazidime resistant Escherichia coli and Klebsiella pneumoniae isolates in Turkish hospitals. Indian journal of medical microbiology 2007; 25(4): 346-350.

19. Shukla I, Tiwari R, Agrawal M. Prevalence of extended spectrum producing Klebsiella pneumoniae in tertiary care hospitals. Indian journal of medical microbiology 2004; 22(2): 87-91.

20. Ullah F, Akbar S, Ahmed J. Antimicrobial susceptibility pattern and ESBL prevalence in Klebsiella pneumoniae from urinary tract infection in the North West of Pakistan. African journal of microbiology research. 2009: 3(11): 676-680.

21. Gonzalez LS, Specer JP. Aminoglycosides: A practical review. Am. Fam. Physician. 1998; 58(8): 1811-1820.
22. Revathi G, Puri J. Bacteriology of burns. Burns 1998; 24(4): 347-349.

23. Procop G, Marion MD, Tuohy J, et al. Cross -class resistance to non B-lactam Antimicrobial in extended spectrum Beta lactamases producing Klebsiella pneumoniae. Am. J clin. Pathol. 2003; 120: 265-267.

24. Ho P, Chow K, Yuen K, et al. Comparison of a noval inhibitor potentiated disc diffusion test with other methods for detection of extended spectrum beta lactamases in Escherichia coli and Klebsiella pneumoniae. Journal of antimicrobial chemotherapy 1998; 42: 4954. 